\title{
"Activation" of Vitamin D by the Liver
}

\author{
G. Ponchon, A. L. Kennan, and H. F. DeLuca \\ From the Departments of Biochemistry and Obstetrics and Gynecology, \\ University of Wisconsin, Madison, Wisconsin 53706
}

A B S T R A C T Isolation of the liver from the circulation of rats eliminates almost completely their ability to convert $[1,2]-{ }^{3} \mathrm{H}$ vitamin $\mathrm{D}_{3}$ into its biologically active metabolite, 25-hydroxycholecalciferol, as well as certain other metabolites. It is concluded that the liver is the major if not the only physiologic site of hydroxylation of vitamin $\mathrm{D}_{3}$ (cholecalciferol) into 25-hydroxycholecalciferol.

The osteodystrophy and the higher requirements for vitamin $\mathrm{D}$ observed in hepatic insufficiencies may be due to an inability of the liver to transform vitamin $D$ into its metabolically active form.

\section{INTRODUCTION}

A major step in understanding the mechanism of action of vitamin $\mathrm{D}$ has been the recent identification of its biologically active metabolite, 25-hydroxycholecalciferol $(1,2)$. This substance is more active than vitamin $D_{3}$ itself in curing rickets when administered in vivo and acts more rapidly in stimulating the intestinal absorption of calcium as well as mobilization of bone (3).

Whereas it has never been possible to demonstrate a direct effect of small doses of vitamin D on bone or intestine, 25-hydroxycholecalciferol has proved to be directly active in vitro in trace amounts on bone resorption (4) and intestinal transport of calcium (5). These new evidences support the concept that 25-hydroxycholecalciferol may be the metabolically active form of vitamin $D_{3}$. It is therefore of major concern to determine the site of its biosynthesis.

Investigations in man (6) and in rats (7) have shown that the disappearance of ${ }^{8} \mathrm{H}$ from the plasma after an intravenous dose of tritiated vitamin $\mathrm{D}_{3}$ is interrupted by a very characteristic rebound of radioactivity after $2-4 \mathrm{hr}$. It has been possible to show that the liver is responsible for this transient increase in plasma radioactivity by quickly releasing into the blood a large por-

Received for publication 25 February 1969 and in revised form 22 May 1969. tion of the dose which had been initially cleared from the plasma and accumulated in the liver. At the very same time, 25-hydroxycholecalciferol starts to accumulate in the plasma and in the tissues (7). These observations led us to postulate the liver as the site of hydroxylation of vitamin $\mathrm{D}_{3}$ into its active metabolite, 25-hydroxycholecalciferol.

The very high incidence and severity of bone dystrophies in patients with severe liver disease has been associated with a controversy concerning the possible role of the liver in the metabolism of calcium and phosphorus. Impaired intestinal absorption of calcium $(8,9)$ and vitamin D (10-14) due to the lack of bile salts has been generally implicated in the etiology of the osteodystrophy. However, several reports indicate that in addition to an occasional poor intestinal absorption of vitamin $\mathrm{D}$, the metabolism and the effects of this vitamin were directly altered by the liver disease. This was based mainly on the higher requirements for vitamin $\mathrm{D}$ usually observed in chronic hepatic insufficiency (1523). In 1956, Atkinson, Nordin, and Sherlock, after careful investigation of 25 cases of prolonged obstructive jaundice stated "it seems possible that destruction of liver cells may interfere with storage or metabolism of vitamin D" (20).

More direct evidence that failure of liver function results in an abnormal metabolism of vitamin $\mathrm{D}$ in man has been provided by Avioli and coworkers (6). They demonstrated an unusually slow plasma disappearance of vitamin $\mathrm{D}_{3}{ }^{3} \mathrm{H}$ associated with a decrease in the vitamin $\mathrm{D}_{3}$ glucuronide fraction in the urine of cirrhotic patients.

The present work demonstrates that in rats the liver is the major, if not the only, physiological site of hydroxylation of vitamin $\mathrm{D}_{3}$ into its active form, 25-hydroxycholecalciferol. It is suggested that severe liver insufficiency in man results in a lack of 25-hydroxycholecalciferol, or of an equivalent active metabolite of vitamin $\mathrm{D}$. This would provide an experimental explanation of the higher requirements for vitamin $D$ to alleviate the hepatic osteodystrophy. 


\section{METHODS}

The experiments were designed to investigate the ability of hepatectomized rats to convert vitamin $\mathrm{D}_{3}{ }^{3} \mathrm{H}$ into 25 -hydroxycholecalciferol $-^{8} \mathrm{H}$. Since total ablation of the liver was not technically possible, surgical vascular disconnection of the liver was performed and considered equivalent to an actual hepatectomy.

Holtzman male rats (average weight $140 \mathrm{~g}$ ) were fed the vitamin D-deficient diet 11 of Guroff, DeLuca, and Steenbock ( $\mathrm{Ca}, 0.47 \% ; \mathrm{P}, 0.30 \%$ ) (24) for a period of $4-8 \mathrm{wk}$. At this time they were judged vitamin $\mathrm{D}$-deficient because of lack of growth and low serum calcium values (25). They were subjected to surgery under ether anesthesia. A portocaval shunt was created by vascular suture, followed by the ligation and section of the hepatic artery and bile duct tree 4 days later. Because the liver was intimately attached to the vena cava, it was not possible to separate these two tissues and to ligate the hepatic vein. The rats recovered extremely well from the first operation, and lost less than $10 \%$ of body weight between the two surgeries. Just at the end of the second operation, $10 \mathrm{IU}(0.25 \mu \mathrm{g})\left[1,2-{ }^{3} \mathrm{H}\right]$-vitamin $\mathrm{D}_{3}$ (26) (SA $24,453 \mathrm{dpm} / \mathrm{IU}$ or $0.44 \mu \mathrm{c} / \mu \mathrm{g}$ ) dissolved in $0.05 \mathrm{ml}$ of plasma from vitamin D-deficient rats was injected intravenously via the jugular vein (27). The radiochemical purity of $\left[1,2-{ }^{8} \mathrm{H}\right]$-vitamin $\mathrm{D}_{3}$ was assessed by chromatography on silicic acid column, UV spectrophotometry ( $\lambda$ maximum $265 \mathrm{~m} \mu ; \epsilon, 18,200$ ), and biological assay using the line-test method in rachitic rats (28). "Hepatectomized" rats had a very limited survival, and were sacrificed after $4 \mathrm{hr}$. As already described, (7, 26) plasma, liver, and the two target tissues of vitamin $\mathrm{D}$ action, bones and small intestines, were analyzed for total tritium content after combustion analysis (29) and after lipid extraction in chloroform-methanol-water system (30). The "chloroform-soluble" metabolites of vitamin $\mathrm{D}_{3}$ were separated by chromatography on silicic acid ${ }^{1}$ columns $(55 \times 1.5 \mathrm{~cm})$. Samples dissolved in $5-10 \mathrm{ml}$ of redistilled petroleum ether (bp $67^{\circ} \mathrm{C}$ ) were applied on columns and subsequently chromatographed by gradients of solvents of increasing polarity in the given order: $(a)$ exponential gradient obtained by superimposing a holding chamber containing 250 $\mathrm{ml}$ of $75 \%$ diethyl ether in petroleum ether on a constantvolume, Erlenmeyer mixing chamber containing $230 \mathrm{ml}$ of $100 \%$ petroleum ether; $(b)$ exponential gradient by adding $400 \mathrm{ml}$ of $100 \%$ diethyl ether to the empty holding chamber; (c) exponential gradient by adding to the holding chamber $300 \mathrm{ml}$ of $5 \%$ methanol in diethyl ether; $(d)$ exponential gradient by adding to the holding chamber $200 \mathrm{ml}$ of $50 \%$ methanol in diethyl ether; and $(e)$ batch elution with $200 \mathrm{ml}$ of absolute methanol applied on the column without the intermediate mixing chamber.

$10-\mathrm{ml}$ fractions were collected and their radioactivity measured. The chromatographic peaks were estimated as per cent of the radioactivity chromatographed, and the total amount of these metabolites in each plasma or tissues was expressed as per cent of the vitamin $\mathrm{D}_{\mathbf{3}^{-}}{ }^{3} \mathrm{H}$ dose. "Aqueoussoluble" and "nonextractable" radioactivites were separately recorded.

Tritiated water resulting from combustion was taken up in combustion counting solution, made of $4 \mathrm{~g}$ of 2,5-diphenyloxazole (PPO), $50 \mathrm{mg}$ of dimethyl p-bis[2-(5-phenyloxazolyl)] benzene (dimethyl-POPOP), $200 \mathrm{ml}$ of absolute ethanol, and toluene AR ad 1 liter (26). The other samples were dried in

\footnotetext{
${ }^{1}$ Silicic acid, 100 mesh, Mallinckrodt, St. Louis, Mo.
}

TABLE I

Plasma and Tissue Radioactivities $4 \mathrm{hr}$ after Intravenous Injection of $10 \mathrm{IU}$ Vitamin $\mathrm{D}_{\mathrm{r}^{-3}} \mathrm{H}$

\begin{tabular}{llcccc}
\hline \multicolumn{1}{c}{ Samples } & & Total RA* & $\begin{array}{c}\text { Chloroform- } \\
\text { soluble }\end{array}$ & $\begin{array}{c}\text { Aqueous- } \\
\text { soluble }\end{array}$ & $\begin{array}{c}\text { Non- } \\
\text { extractable }\end{array}$ \\
\hline \multirow{3}{*}{ Plasma } & & \% dose & \% of sample radioactivity \\
& HPX & $22.8 \pm 1.8$ & 99.2 & 0.8 & 0 \\
Liver & Intact & $20.6 \pm 0.9$ & 99.6 & 0.3 & 0.05 \\
& HPX & 9.6 & 99.0 & 0.9 & 0.1 \\
Small intestine & Intact & 34.2 & 99.1 & 0.5 & 0.4 \\
& HPX & 1.1 & 92.8 & 7.2 & 0 \\
Bones & Intact & 2.5 & 85.4 & 12.0 & 2.6 \\
& HPX & 8.7 & 92.0 & 3.9 & 4.1 \\
& Intact & 12.8 & 85.4 & 13.9 & 0.6 \\
\hline
\end{tabular}

HPX = "hepatectomized" rats.

* Mean ISEM are given for the "total radioactivity" in plasma. Other data represent values from pooled samples of 4 rats.

counting vials and dissolved in toluene counting solution consisting of $2.0 \mathrm{~g}$ of PPO and $100 \mathrm{mg}$ of dimethyl-POPOP in 1 liter of toluene. Some samples were dissolved in 0.5$2.0 \mathrm{ml}$ of "NCS" solubilizer" (31) before adding the toluene counting solution. All the radioactivity measurements were performed in triplicate with a Packard Tri-Carb 3003 liquid scintillation counter equipped with an automatic external standardization system 3951 (32).

The metabolism of vitamin $\mathrm{D}_{\mathbf{3}}{ }^{-} \mathrm{H}$ into 25-hydroxycholecalciferol- ${ }^{8} \mathrm{H}$ and other metabolites during a $4 \mathrm{hr}$ period was compared in three sets of control experiments. Using vitamin D-deficient rats of equivalent weight $(a)$ a group of 4 "intact rats" were injected intravenously with 10 IU [1,2${ }^{3} \mathrm{H}$ ]-vitamin $D_{3}$ without previous surgery. Plasma and tissues were analyzed as in the "hepatectomized rats." (b) A group of three "stress rats" were bled to $\frac{2}{3}$ of their blood volume by cardiac puncture under ether anesthesia, then sham-operated by laparatomy and manipulation of the viscera immediately before the intravenous injection of labeled vitamin $\mathrm{D}_{3}$. Only plasma was analyzed. (c) Two rats received a portocaval shunt without ligation of the hepatic artery 4 days before the administration of the tritiated vitamin $D_{3}$ ("shunt rats").

\section{RESULTS}

Plasma and tissue metabolites in "hepatectomized" and "intact" rats. Table I shows that there was no difference in the plasma radioactivities and its partitioning between "hepatectomized" (HPX) and intact rats. The presence of $9.6 \%$ of the dose in the livers of "hepatectomized" rats whose portal vein and hepatic artery were severed was surprising. Since all peritoneal and visceral adherences were freed during the operation, the most likely explanation is a reflux of blood from the vena cava to the liver through the nonligated hepatic vein Small intestines and bones of intact rats seemed to contain more tritium and aqueous-soluble radioactivity than the hepatectomized rats but the difference might not be significant.

' Nuclear-Chicago Corporation, Chicago, Ill.

"Activation" of Vitamin $D$ by the Liver 
TABLE II

Plasma and Tissue Chromatographic Fractions $4 \mathrm{hr}$ after Intravenous Injection of $10 \mathrm{IU}$ Vitamin $\mathrm{D}_{5}{ }^{8} \mathrm{H}$

\begin{tabular}{|c|c|c|c|c|c|c|c|c|c|c|}
\hline Samples & & I & $\mathrm{II}_{\boldsymbol{a}}$ & II & III & $\mathrm{IV}_{a}$ & IV & $\mathrm{V}_{a+b}$ & $\mathrm{VI}_{a+b}$ & $\mathrm{VII}_{a+b}$ \\
\hline Plasma & $\begin{array}{l}\text { HPX } \\
\text { Intact }\end{array}$ & $\begin{array}{c}0.2 \pm 0.06 \\
0.3\end{array}$ & $\overline{0.2}$ & $\begin{array}{c}1.6 \pm 0.2 \\
1.9\end{array}$ & $\begin{array}{c}93.2 \pm 0.4 \\
73.1\end{array}$ & $\begin{array}{l}0.7 \\
1.1\end{array}$ & $\begin{array}{c}1.2 \pm 0.1 \\
16.0\end{array}$ & $\begin{array}{c}1.0 \pm 0.2 \\
4.3\end{array}$ & $\begin{array}{c}0.7 \pm 0.2 \\
1.4\end{array}$ & $\begin{array}{c}0.5 \pm 0.1 \\
0.9\end{array}$ \\
\hline Liver & $\begin{array}{l}\mathrm{HPX} \\
\text { Intact }\end{array}$ & $\begin{array}{l}0.6 \\
1.1\end{array}$ & $\begin{array}{l}0.2 \\
1.1\end{array}$ & $\begin{array}{r}11.3 \\
3.1\end{array}$ & $\begin{array}{l}81.4 \\
88.8\end{array}$ & - & $\begin{array}{l}1.2 \\
1.7\end{array}$ & $\begin{array}{l}1.4 \\
1.2\end{array}$ & $\begin{array}{l}0.8 \\
1.2\end{array}$ & $\begin{array}{l}1.1 \\
0.3\end{array}$ \\
\hline Small intestine & $\begin{array}{l}\text { HPX } \\
\text { Intact }\end{array}$ & $\begin{array}{l}0.4 \\
1.5\end{array}$ & $\begin{array}{l}0.5 \\
0.4\end{array}$ & $\begin{array}{l}6.2 \\
3.0\end{array}$ & $\begin{array}{l}83.6 \\
65.1\end{array}$ & $\overline{1.6}$ & $\begin{array}{r}1.8 \\
14.1\end{array}$ & $\begin{array}{l}3.3 \\
4.8\end{array}$ & $\begin{array}{l}0.6 \\
4.5\end{array}$ & $\begin{array}{l}2.5 \\
3.2\end{array}$ \\
\hline Bones & $\begin{array}{l}\mathrm{HPX} \\
\text { Intact }\end{array}$ & $\begin{array}{l}2.7 \\
1.8\end{array}$ & $\overline{0.3}$ & $\begin{array}{l}7.3 \\
5.0\end{array}$ & $\begin{array}{l}80.1 \\
75.7\end{array}$ & $\overline{1.4}$ & $\begin{array}{l}0.8 \\
8.9\end{array}$ & $\begin{array}{l}3.4 \\
3.3\end{array}$ & $\begin{array}{l}2.1 \\
1.3\end{array}$ & $\begin{array}{l}1.5 \\
0.5\end{array}$ \\
\hline
\end{tabular}

The data are expressed as per cent of chromatographed radioactivity. Mean \pm SEM are given for the plasma of hepatectomized rats. Other data represent values from pooled samples of 4 rats.

It will be reported separately ${ }^{3}$ that the present chromatographic system separates up to 12 distinct radioactive peaks from the chloroform extracts of plasma and tissues after injection of tritiated vitamin $\mathrm{D}_{3}$.

Only peaks I, III, and IV have been so far identified as respectively vitamin $\mathrm{D}_{\mathbf{3}}$ esters (33), unaltered vitamin $\mathrm{D}_{\mathbf{3}}$ (34), and 25-hydroxycholecalciferol $(1,2)$. In addition to the most biologicaly active metabolite 25 -hydroxycholecalciferol and unaltered vitamin $D_{z}$, only the esters and peak II display consistent but smaller antirachitic activity $(3,34,35) .^{3}$

$4 \mathrm{hr}$ after intravenous vitamin $\mathrm{D}_{3}{ }^{3} \mathrm{H}$, most of the radioactivity in the plasma and tissues of intact rats was accounted for by the unchanged vitamin (peak III) and 25-hydroxycholecalciferol (peak IV) (Table II). In contrast, the proportion of peak IV is vanishingly small in the plasma and tissues of "hepatectomized" animals. The significance of such small amounts is questionable, since it is difficult to clearly define a faint chromatographic peak as shown in Fig. 1. This figure compares the chromatographic profile of lipid extracts of plasma from one "hepatectomized" rat with that from a pool of four intact rats. The individual chromatographic profiles obtained in each "hepatectomized" rat were very similar as indicated by the small SEM in Table II. It is quite possible that the traces of peak IV observed in our hepatectomized rats originate from the incompletely isolated liver. The radioactivity found in those livers (Table I) suggests that some blood has refluxed in through the nonligated hepatic vein. The minimal amounts of 25hydroxycholecalciferol thus formed in functionally impaired hepatocytes might find their way out to the plasma as well.

It may be concluded that hepatectomized rats do not hydroxylate a significant proportion of vitamin $D_{s}$ into

${ }^{3}$ Ponchon, G., and H. F. DeLuca. Metabolites of vitamin $\mathrm{D}_{3}$ and their biologic activity. $J$. Nutr. In press. 25-hydroxycholecalciferol. However, the possibility that surgical stress might interfere with the hydroxylation of vitamin $D_{3}$ in other tissues required further investigation.

Plasma vitamin Ds metabolites in "stress" and "shunt" rats. Since 25-hydroxycholecalciferol accumulated mainly in the plasma compartment the following experiments were limited to the plasma. In addition to the evaluation of the surgical stress, the ability of the rats with only a portocaval shunt to metabolize vitamin D

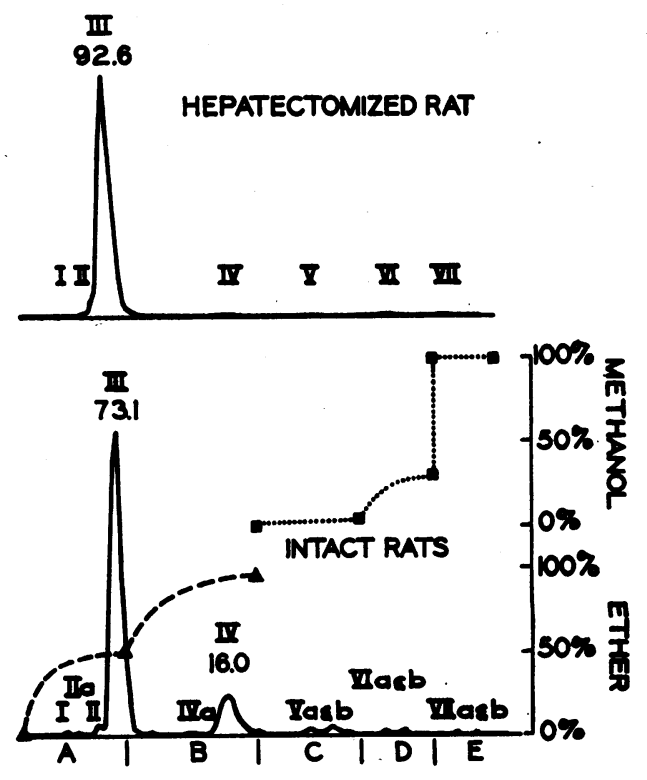

FIgURE 1 Silicic acid column chromatographic profile of radioactivity from lipid extract of plasma obtained $4 \mathrm{hr}$ after i. . injection of $10 \mathrm{IU}\left[1,2{ }^{8} \mathrm{H}\right]$-vitamin $\mathrm{D}_{3}$ to vitamin $\mathrm{D}$-deficient "hepatectomized" and "intact" rats. The upper profile represents the plasma of one individual "hepatectomized" rat, and the lower profile corresponds to a pool of plasma from four intact rats. 
TABLE III

Plasma Chromatographic Fractions in "Stress" and

"Shunt" Rats $4 \mathrm{hr}$ after Intravenous Injection of $10 \mathrm{IU}$ Vitamin $\mathrm{D}_{\mathbf{z}^{-3}} \mathrm{H}$

\begin{tabular}{|c|c|c|c|c|c|c|c|c|c|}
\hline $\begin{array}{l}\text { Groups } \\
\text { of rats }\end{array}$ & I & $\mathrm{II}_{a}$ & II & III & $\mathrm{IV}_{a}$ & IV & $V_{a+b}$ & $\mathrm{VI}_{a+b}$ & $\mathrm{VII}_{a+b}$ \\
\hline Stress & 0.2 & 0.2 & 1.0 & 72.1 & 0.4 & 18.3 & 2.6 & 1.7 & 2.0 \\
\hline Shunt & 0.5 & 0.1 & 1.7 & 82.7 & 1.0 & 6.4 & 3.2 & 1.2 & 1.5 \\
\hline
\end{tabular}

The data are expressed as per cent of chromatographed radioactivity. The values are from pooled samples of 3 "stress" and 2 "shunt" rats.

was compared with the "intact" and "hepatectomized" animals. It is evident from Table III that the surgical stress did not interfere with the normal conversion of vitamin $D_{s}$ into 25-hydroxycholecalciferol. The plasma radioactivity found in the form of 25-hydroxycholecalciferol ( $18.3 \%$ in peak IV) was similar to the $16.0 \%$ seen in "intact" animals. On the other hand, the creation of a portocaval shunt seemed to handicap the ability of the rats to hydroxylate vitamin $\mathrm{D}_{3}$ into 25-hydroxycholecalciferol. Only $6.4 \%$ of the plasma radioactivity was represented by this metabolite in the shunted group.

The "stress" rats which have lost more than $\frac{1}{3}$ of their blood volume, have less radioactivity in their plasma compartment $\left[11.6 \pm 1.5 \%\right.$ (3) ${ }^{4}$ of dose] than intact rats [20.6 $\pm 0.9 \%(4)]$. Since vitamin D and 25-hydroxycholecalciferol are known to bind to certain plasma proteins (36-39), a decrease of these carriers by blood loss likewise might well reduce the proportion of the dose held in the plasma compartment.

"Shunt" rats seem to have a lower level of plasma radioactivity ( 17.3 and $15.5 \%$ of dose) than the "intact" animals. As a result of their smaller conversion of vitamin $D_{8}$ into 25-hydroxycholecalciferol, the quantity of this metabolite in plasma is much reduced (1.0\% of dose).

\section{DISCUSSION}

Whereas the role of the mammalian liver as a storage organ for vitamin D is still a matter of debate (40), its function in the early metabolic events of vitamin $D$ becomes more and more evident. Kodicek, Cruickshank, and Ashby (41) were the first to call the attention to the very rapid and large uptake of injected labeled vitamin $\mathrm{D}$ by the liver (more than $50 \%$ of the dose in 30 $\mathrm{min})$. This is apparently the case with doses ranging from 0.1 to $1000 \mu \mathrm{g}(26,42,43)$. The quick release of this radioactivity from the liver strongly suggests an important metabolic function of the liver $(7,40)$. Previ-

\footnotetext{
‘ Mean $\pm_{\mathrm{SEM}}$ (number of rats).
}

ous observations led us to suggest that the liver was responsible for the conversion of vitamin $D_{3}$ into its active metabolite, 25-hydroxycholecalciferol (7).

The present experiments demonstrate that the liver is necessary indeed for the biologic hydroxylation of vitamin $\mathrm{D}_{\mathbf{3}}$ into its metabolite, 25-hydroxycholecalciferol, in rats. "Hepatectomy" results in an absence of this metabolite in the plasma and tissues of rats while impaired liver function by portocaval shunt reduced its proportion. That this effect is not due to the metabolic disorders induced by surgical stress is shown by an entirely normal production of 25-hydroxycholecalciferol in sham-operated and bled rats. However, one cannot definitely refute the criticism that metabolic alterations due to acute liver insufficiency itself might interfere with the normal conversion of vitamin $\mathrm{D}$ possibly occurring in other tissues. It seems unlikely however that it would result in a total absence of 25-hydroxycholecalciferol. On the other hand the possibility that some tissues other than the liver could hydroxylate vitamin $D_{s}$ at very high concentrations of vitamin $\mathrm{D}_{3}$ substrate may not be regarded as a physiologic mechanism and is out of the scope of this work.

Theoretically the liver could participate in the formation of 25-hydroxycholecalciferol in two different ways: (a) by converting vitamin $\mathrm{D}$ into an intermediate compound subsequently transported to other tissues where 25-hydroxycholecalciferol would be made, or $(b)$ by direct hydroxylation of vitamin $D_{z}$ in the hepatocytes. The formation of an intermediate is not substantiated by the failure to observe such a precursor in blood or tissues. Another possibility suggested earlier (39) is that the liver might liberate vitamin D from its lipoprotein complex and facilitate its binding to specific plasma proteins. These carriers would transport effciently vitamin $\mathrm{D}$ to peripheral tissues where the hydroxylation would occur. However, vitamin D binds also to these proteins when added to serum in vitro, and therefore this function of the liver would not be essential.

Rather, all evidence supports the idea that the liver directly hydroxylates vitamin $\mathrm{D}_{\mathbf{z}}$ into 25-hydroxycholecalciferol. Previous work (7) has shown that the appearance of 25-hydroxycholecalciferol in plasma is coupled with the release of radioactive material from the liver without a time lag. A delay would have been expected if an intermediary metabolite had been formed. Moreover, work in progress in our laboratory (44) shows that perfused isolated liver of rats converts vitamin $D_{3}$ into 25-hydroxycholecalciferol and in vitro incubation of rat liver homogenate effects the same hydroxylation.

Surprisingly, only a very small proportion of the liver radioactivity is represented by 25 -hydroxycholecalciferol, whereas the bulk of it is still unchanged vitamin $D_{\mathbf{8}}{ }^{8} \mathrm{H}$.

"Activation" of Vitamin D by the Liver

2035 
Although this proportion increased with time after the injection of vitamin $\mathrm{D}_{3}{ }^{8} \mathrm{H}$, the liver has characteristically a much lower concentration of 25-hydroxycholecalciferol than the plasma, bone, and intestine. ${ }^{3}$ It may be suggested that the accumulation of 25-hydroxycholecalciferol is dependent upon specific receptor sites found in the target tissues but not in the liver $(45,46)$.

It has long been recognized that severe liver insuffi= ciency results in abnormalities of the skeleton and disturbances in calcium-phosphorus metabolism (14-16, 1823, 47-52). However, unclear definition of the bone lesions and hepatic disease was a cause of controversy. The skeleton becomes consistently osteopenic with various degrees of osteoporosis and osteomalacia or rickets. Although it appears that osteoporotic changes do not usually respond to vitamin $\mathrm{D}$ therapy alone $(18,20,49$, 52 ), several clinical observations emphasize the higher requirements for vitamin $\mathrm{D}$ even in the cases of osteomalacia or rickets $(15,17,18-23)$. Since osteoporosis and malacia are most often associated we will use the general term of "hepatic osteodystrophy" for the sake of simplicity.

The main question is how the liver is involved in these metabolic disorders. Simple biliary deficiency as encountered in the experimental or clinical biliary fistulae should be distinguished from alteration in the hepatic parenchyma (liver cirrhosis). Unfortunately, severe chronic liver insufficiency usually associates in various proportions with cirrhosis and bile retention. It is now clear that bile salts improve absorption of calcium (8, 9) and are necessary for the absorption of vitamin $D$ (10-14). This certainly accounts to a large extent for the osteodystrophy resistant to oral administration of vitamin D observed in biliary obstruction without major liver parenchymal damage or in bile fistulae $(11,47,53$, 54). However, as pointed out by Atkinson et al. (20), the evolution of the bone lesions in severe hepatocellular deficiency is much faster than one would expect from simple malabsorption of vitamin $\mathrm{D}$. The authors stated that in such cases "it seems possible that destruction of liver cells may interfere with storage or metabolism of vitamin D." Parenteral treatment with large doses of vitamin $\mathrm{D}$, in addition to other measures, was advocated to match the higher requirements for vitamin D.

In 1934, Greaves and Schmidt showed that vitamin $D_{2}$ given orally or subcutaneously to jaundiced rachitic rats does not heal the rickets as it does in the normal rachitic animals. But they suggested this was due to metabolic impairment of the osteogenic cells by the jaundice (55).

The present experiments provide evidence that the liver contributes and (or) is necessary in the rats to the effect of vitamin $D_{s}$ by converting it into its active form, 25-hydroxycholecalciferol. Since the metabolic pathway of vitamin $D_{3}$ appears qualitatively similar
$(6,40)$ we suggest that gross liver insufficiency in man results in a deficient formation of 25-hydroxycholecalciferol or of an equivalent vitamin D metabolite.

\section{ACKNOWLEDGMENTS}

This work was published with the approval of the Director of the Wisconsin Agricultural Experiment Station, and was supported by U. S. Public Health Service grants AM-0580007 and $A M-09852-04$.

\section{REFERENCES}

1. Blunt, J. W., H. F. DeLuca, and H. K. Schnoes. 1968. 25-hydroxycholecalciferol: a biologically active metabolite of cholecalciferol. Chem. Commun. 801.

2. Blunt, J. W., H. F. DeLuca, and H. K. Schnoes. 1968. 25-hydroxycholecalciferol. A biologically active metabolite of vitamin $\mathrm{D}_{3}$. Biochemistry. 7: 3317.

3. Blunt, J. W., Y. Tanaka, and H. F. DeLuca. 1968. The biological activity of 25-hydroxycholecalciferol, a metabolite of vitamin $\mathrm{D}_{3}$. Proc. Nat. Acad. Sci. U.S. A. 61 : 717.

4. Trummel, C. L., L. G. Raisz, J. W. Blunt, and H. F. DeLuca. 1969. 25-hydroxycholecalciferol: stimulation of bone resorption in tissue culture. Science (Washington). 163: 1450 .

5. Olson, E. B., Jr., and H. F. DeLuca. 1969. Calcium transport in a perfused rat intestine. Science (Washington). 165: 405 .

6. Avioli, L. V., S. W. Lee, J. E. McDonald, J. Lund, and H. F. DeLuca. 1967. Metabolism of vitamin $\mathrm{D}_{3}{ }^{8} \mathrm{H}$ in human subjects: distribution in blood, bile, feces, and urine. J. Clin. Invest. 46: 983.

7. Ponchon, G., and H. F. DeLuca. 1969. The role of the liver in the metabolism of vitamin D. J. Clin. Invest. 48: 1273.

8. Coates, M. E., and E. S. Holdsworth. 1961. Vitamin Ds and absorption of calcium in the chick. Brit. J. Nutr. $15: 131$.

9. Webling, D. d'A., and E. S. Holdsworth. 1965. The effect of bile, bile acids and detergents on calcium absorption in the chick. Biochem. J. 97: 408.

10. Greaves, J. D., and C. L. A. Schmidt. 1934. Further experiments on the rôle played by bile in the absorption of vitamin D in the rat. Univ. Calif. Publ. Physiol. 8: 43.

11. Taylor, N. B., C. B. Weld, and J. F. Sykes. 1935. The relation of bile to the absorption of vitamin D. Brit. J. Exp. Pathol. 16: 302.

12. Heymann, W. 1937. Metabolism and mode of action of vitamin D. IV. Importance of bile in the absorption and excretion of vitamin D. J. Biol. Chem. 122: 249.

13. Schachter, D., J. D. Finkelstein, and S. Kowarski. 1964. Metabolism of vitamin D. I. Preparation of radioactive vitamin $\mathrm{D}$ and its intestinal absorption in the rat. J. Clin. Invest. 43: 787

14. Thompson, G. R., B. Lewis, and C. C. Booth. 1966. Absorption of vitamin $\mathrm{D}_{\mathbf{3}}{ }^{\mathbf{3}} \mathrm{H}$ in control subjects and patients with intestinal malabsorption. J. Clin. Invest. 45: 94.

15. Gerstenberger, H. J. 1933. Rachitis hepatica. Monatsch. Kinderh. 56: 217.

16. Ask-Upmark, E. 1939. Osteomalacia hepatica. Acta Med. Scand. 99: 204

17. Heymann, W. 1938. Metabolism and mode of action of vitamin D. III. Importance of the liver for its antirachitic efficacy. Amer. J. Dis. Child. 55: 913. 
18. Krahulic, L., M. P. Shoob, S. Morales, S. E. Snyderman, and L. E. Holt, Jr. 1952. Congenital obliteration of the bile ducts with particular reference to dietotherapy. J. Pediat. $41: 774$.

19. Friis-Hansen, B. 1956. Neonatal hepatitis with osteomalacia. Acta Pediat. 45: 376.

20. Atkinson, M., B. E. C. Nordin, and S. Sherlock. 1956. Malabsorption and bone disease in prolonged obstructive jaundice. Quart. J. Med. 25: 299.

21. Levin, E. J. 1956. Congenital biliary atresia with emphasis on skeletal abnormalities. Radiology. 67: 714 .

22. Alagille, D. 1958. Retentissment osseux des affections hepatobiliaires chez le nourrisson et l'enfant. Bull. Soc. Med. Hop. Paris. 74: 717.

23. Kehayoglou, A. K., C. D. Holdsworth, J. E. Agnew, M. J. Whelton, and S. Sherlock. 1968. Bone disease and calcium absorption in primary biliary cirrhosis. Lancet. $1: 715$.

24. Guroff, G., H. F. DeLuca, and H. Steenbock. 1963. Citrate and action of vitamin $\mathrm{D}$ on calcium and phosphorus metabolism. Amer. J. Physiol. 204: 833.

25. Steenbock, H., and D. C. Herting. 1955. Vitamin D and growth. J. Nutr. $57: 449$.

26. Neville, P. F., and H. F. DeLuca. 1966. The synthesis of $\left[1,2{ }^{8} \mathrm{H}\right]$ vitamin $D_{3}$ and the tissue localization of a $0.25 \mu \mathrm{g}$ (10 I.U.) dose per rat. Biochemistry. 5: 2201.

27. Ponchon, G., and H. F. DeLuca. 1969. Ethanol-induced artifacts in the metabolism of ${ }^{8} \mathrm{H}$-vitamin $\mathrm{D}_{3}$. Proc. Soc. Exp. Biol. Med. 131: 727 .

28. United States Pharmacopoeia. 1955. P. A. Easton and P. G. Mach, editors. 15th edition. 889.

29. Kelly, R. G., E. A. Peets, S. Gordon, and D. A. Buyske. 1961. Determination of $\mathrm{C}^{14}$ and $\mathrm{H}^{2}$ in biological samples by Schöniger combustion and liquid scintillation techniques. Anal. Biochem. 2: 267.

30. Bligh, E. G., and W. J. Dyer. 1959. A rapid method of total lipide extraction and purification. Can. J. Biochem. Physiol. 37: 911.

31. Hansen, D. L., and E. T. Bush. 1967. Improved solubilization procedures for liquid scintillation counting of biological materials. Anal. Biochem. 18: 320.

32. DeWachter, R., and W. Fiers. 1967. External standardization in liquid scintillation counting of homogeneous samples labeled with one, two or three isotopes. Anal. Biochem. 18: 351.

33. Lund, J., H. F. DeLuca, and M. Horsting. 1967. Formation of vitamin D esters in vivo. Arch. Biochem. Biophys. 120: 513 .

34. Norman, A. W., J. Lund, and H. F. DeLuca. 1964. Biologically active form of vitamin $D_{8}$ in kidney and intestine. Arch. Biochem. Biophys. 108: 12.

35. Lund, J., and H. F. DeLuca. 1966. Biologically active metabolite of vitamin $\mathrm{D}_{\mathrm{s}}$ from bone, liver, and blood serum. J. Lipid Res. $7: 739$.

36. Thomas, W. C., Jr., H. G. Morgan, T. B. Connor, L. Haddock, C. E. Bills, and J. E. Howard. 1959. Studies on antiricketic activity in sera from patients with disorders of calcium metabolism and preliminary observations on the mode of transport of vitamin D in human serum. $J$. Clin. Invest. 38: 1078

37. Chalk, K. J. I., and E. Kodicek. 1961. The association of ${ }^{14}$ C-labeled vitamin $\mathrm{D}_{2}$ with rat serum proteins. Biochem. J. 79: 1.

38. Chen, P. S., Jr., and K. Lane. 1965. Sedum protein binding of vitamin $\mathrm{D}_{3}$. Arch. Biochem. Biophys. 112: 70.

39. Rikkers, H., and H. F. DeLuca. 1967. An in vivo study of the carrier proteins of ${ }^{8} \mathrm{H}$-vitamin $\mathrm{D}_{3}$ and $\mathrm{D}_{4}$ in rat serum. Amer. J. Physiol. 213: \}\{0.

40. DeLuca, H. F. 1967. Mechanism of action and metabolic fate of vitamin D. Vitamins Hormones. 25: 315.

41. Kodicek, E., E. M. Cruickshank, and D. R. Ashby. 1960. The metabolism of ${ }^{14} \mathrm{C}$-labeled vitamin $\mathrm{D}_{2}$ injected intracardially into rats. Biochem. J. 76: 15P.

42. Norman, A. W., and H. F. DeLuca. 1963. The preparation of $\mathrm{H}^{3}$-vitamin $\mathrm{D}_{2}$ and $\mathrm{D}_{3}$ and their localization in the rat. Biochemistry. 2: 1160

43. DeLuca, H. F., M. Weller, J. W. Blunt, and P. F. Neville. 1968. Synthesis, biological activity and metabolism of $22,23-{ }^{8} \mathrm{H}$-vitamin $\mathrm{D}_{4}$. Arch. Biochem. Biophys. 124: 122.

44. Horsting, M., and H. F. DeLuca. 1969. Enzymatic conversion of cholecalciferol to 25-hydroxycholecalciferol. Federation Proc. 28: 351. (Abstr.)

45. Stohs, S. J., and H. F. DeLuca. 1967. Subcellular location of vitamin $\mathrm{D}$ and its metabolites in intestinal mucosa after a 10 I.U. dose. Biochemistry. 6: 3338 .

46. Haussler, M. R., J. F. Myrtle, and A. W. Norman. 1968. The association of a metabolite of vitamin $D_{3}$ with intestinal mucosa chromatin in vivo. J. Biol. Chem. 243: 4055.

47. Buchbinder, W. C., and R. Kern. 1927. Blood calcium deficiency in experimental obstructive jaundice. Amer. J. Physiol. 80: 273.

48. Mayor, G. 1942. Hepatogene osteodystrophien. Beitr. Pathol. Anat. Allg. Pathol. 106: 408.

49. Houet, R. 1948. Recherches sur le metabolisme de la vitamine D. IV. Recherches sur la pathogenie du soitdisant "Rachitisme Hepatique." Ann. Paediat. 170: 233.

50. Cocchi, U. 1951. Hepatogene Osteoporosen. Radiol. Clin. 20: 362 .

51. Roberts, M. H., and C. Sullivan. 1955. Influence of the liver on bone metabolism. J. Amer. Med. Assoc. 159: 1002.

52. Lichtwitz, A., M. Cachin, D. Hioco, M. Tutin, and S. DeSeze. 1959. Le syndrome phosphocalcique des cirrhoses. Sem. Hop. Paris. 35: 2399.

53. Tamman, H. 1928. Über die Beeinflussing der porotis hen Osteomalazie nach Gallenfistel durch D-Vitamin. Bruns. Beitr. Klin. Chir. 142: 83

54. Loewy, G. 1931. Derivation totale de la bile hors du tube digestif. Hypertrophie des parathyroides. Osteomalacie. Presse Med. 39: 1627.

55. Greaves, J. D., and C. L. A. Schmidt. 1934. The action of Viosterol in jaundiced rachitic rats. Univ. Calif. Publ Physiol. 8: 49. 